給食経営管理論臨地実習の宽習内容に関する実態調査

\author{
加賀谷みえ子 ·大谷香代・河合潤子 \\ (椙山女学園大学) \\ (平成25年 1 月28日受付，平成25年11月13日受理）
}

\title{
Survey on the training content of food service management of field practice
}

\author{
Mieko Kagaya, Kayo Ootani, Junko Kawai \\ Sugiyama Jogakuen University, 17- 3 , Hoshigaoka-motomachi, Chikusa-ku, Nagoya-shi, Aichi, 464-8662 \\ 干464-8662 愛知県名古屋市千種区星が丘元町17- 3
}

In order to focus on the food service management of field practice, and obtained the basic data for future teaching, a survey on the training content.

(1) For the number of provided meals, less than 1000 meals and more than 1000 meals was $56.6 \%$ and $43.4 \%$, respectively.

(2) Over $50 \%$ of the persons who practiced items was in preprocessing, cooking, meal-setting, providing, oral-communication, dishwashing and cleaning up the cafeteria. The work with emphasis on meal service management has been enforced.

For the ranking of each practiced item, preprocessing was washing vegetables and cutting vegetables, cooking was fry, boil, deep-frying, and mix, while meal setting was the side dish, soup, and main dish.

(3) The ranking of the work of the S group, which is school lunches was preprocessing, cooking, nutrition education, dishwashing, and seasoning measuring. In the meal service facilities, the A group experienced about $80 \%$ more which was meal setting, oral communication, providing, service, and cleaning. The B group experienced $100 \%$ which was preprocessing, cooking, meal setting, menu planning, oral communication, and order training. The B group was a standardized system of work in a place. The practice of B group was a standardized system.

(4) A comparison between the self-evaluation of campus and off-campus training was done. Compared to the campus practice, a significantly higher rating point for any item is clinical practice, thus the effect of the off-campus training practice is shown.

All of the self-evaluation points of field practice were significantly higher than the campus training evaluation. The effect of the off-campus training practice is shown.

( 5 ) About the dietitians business, $91.2 \%$ of the total persons answered to "fully understand or almost understand". The order of the higher degree of understanding was the B group, S group, A group. About food service management, $92.2 \%$ of the total persons answered "understanding very well and well". Based on the evaluation points of each facility, the $\mathrm{S}$ group was high and the A group was lower.

The difference can be confirmed by the training contents of the each facility, thus the training of future leadership challenges became apparent. The difference between the training content can be confirmed by each facility, and the education problem in the future were revealed. 


\section{1. 緒言}

管理栄養士養成課程における臨地実習は，平成14年の 改正栄養士法の施行に伴い, 新カリキュラムで実施され てきた。カリキュラム改正により「臨地実習」は，管理 栄養士の実践教育科目として人を中心とした業務に重点 が置かれ，臨地実習が実践能力を身につけるための重要 な役割を担うこととなった。同時に文部科学省と厚生労 働省から「管理栄養士養成施設における臨地実習及び栄 養士養成施設における校外実習」の実施要領 ${ }^{1)}$ が通知さ れ，その要領に準拠し，目的，実習内容，実習方法で実 施される現状がある。しかし, 新カリキュラムでの臨地 実習が始まって10年が経過し, 給食経営管理領域での臨 地実習内容は，実習先の施設ごとで決定されており，実 習内容にはまだ差がみられる。新カリキュラム体制後に 掲載された論文は，西村ら ${ }^{2,3)}$ の「管理栄養士養成にお ける臨地実習プログラムの開発に関する研究一臨地実習 に対する学生のニーズと実習後の自己評価一」，「管理栄 養士養成における臨地実習プログラムの開発に関する研 究 第 2 報一公衆栄養学領域, 給食管理 (学校) 領域の 実習時間別の検討一」, 北島ら ${ }^{4)}$ の「臨地実習における 実習効果を高めるための検討」その他あるが論文数はま だ十分にあるとはいえない。特に具体的な実習内容をま とめた論文は見当たらない。 $\mathrm{S}$ 大学管理栄養士課程の学 生は, 1 年前期より 3 年の臨地実習に向け, それぞれの 授業担当者は実習目的を達成するために事前の教育段階 から学生の実力の向上を図るべく指導を行っている。し かし学内における前提授業で学習した内容が，短期間の 実習現場で実際に体験できるかの実態は把握できていな い。そこで本研究では, 給食の運営について学ぶ機会と なる給食経営管理論領域に関連する小学校や事業所等の 臨地実習に着目し，今後の授業運営と臨地実習のあり方 を検討する基礎資料を得る目的で，実習内容に関する実 態調査を実施し，若干の知見を得たので報告する。

\section{2. 方法}

\section{（1）調査対象および方法}

対象者は $\mathrm{S}$ 大学管理栄養学科 3 年生で, 平成 24 年 7 月から 8 月に臨地実習を終了した者102名である。調査 時期は平成 24 年 7 月から 8 月の臨地実習終了日から 1 週 間以内とした。対象者は調査結果に影響が及ばないよう， 臨地実習前には本調査があることは知らせずに臨地実習 に取り組ませ，実習後の調査当日に調査の目的と内容， および本調査が成績や実習評価には一切関係がないこと を説明した後，本人の同意を得て実習内容についての実 態調査を実施した。調査は自記入式の質問紙法で行った。 実習施設別は，小学校実習 16 校を $\mathrm{S}$ 群，事業所実習は 受託業者 $\mathrm{A}$ 社・ $\mathrm{B}$ 社をそれぞれ $\mathrm{A}$ 群・ $\mathrm{B}$ 群とした。

\section{表 1 自己評価表}

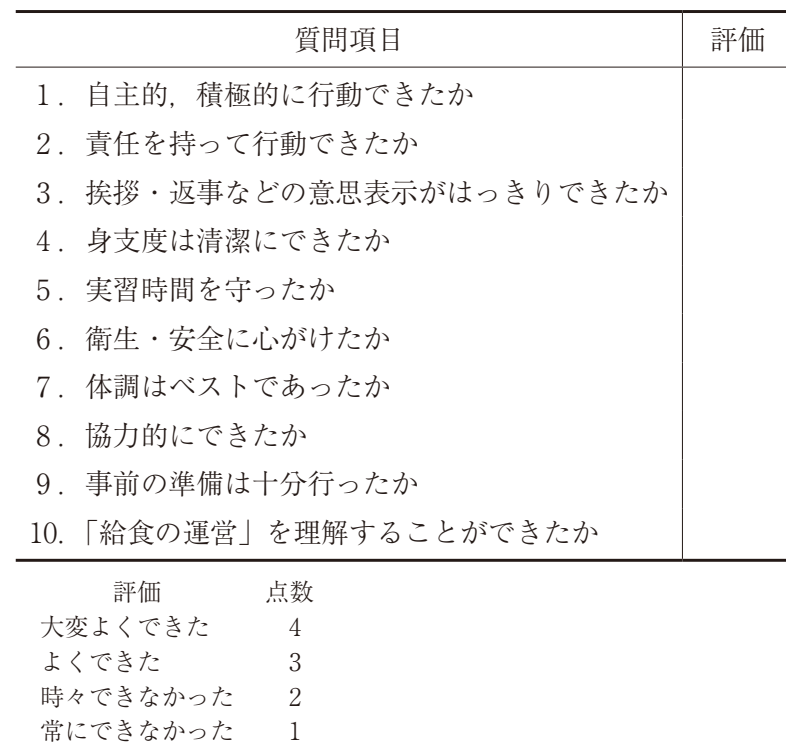

\section{（2）調査内容と解析方法}

調査内容は, 学内実習と同様の自己評価10項目と臨地 実習項目とした。自己評価表は表 1 に示す通りである。 調査項目は給食数, 廚房システム種類, 実習中の課題, 体験した作業の有無とその他の54項目および 4 段階評定 （4点：大変よくできた， 3 点：よくできた， 2 点：時々 できなかった，1点：常にできなかった）による自己評 価10項目とし, 項目内容は学内実習ノート（建帛社）の 自己評価表 ${ }^{5}$ に準じた。作業項目は学内での給食経営管 理実習で実際に実施している内容等とした。給食運営臨 地実習後「学内実習の体験が臨地実習で役立ったか」,「特 定給食施設の栄養士の仕事内容が把握できたか」，「給食 施設別に給食の運営を理解することができたか」の項目 について，5段階評価させた。結果の集計と分析は SPSS ver.19を使用した。業者別, 作業別等で比較し, 検 定は $\chi^{2}$ 検定および $t$ 検定を用いて, 有意水準 $5 \%$ 未満を 有意差があると判定した。

\section{3. 結 果}

\section{（1）対象者の大学入学から臨地実習までの教育概要}

対象者への大学入学から臨地実習までの 2 年間の具体 的な教育内容を表 2 に示した。 $\mathrm{S}$ 大学では 1 年前期に調 理学の講義, 後期には調理学実習と給食経営管理 I の講 義， 2 年前期に給食経営管理 II の講義，後期には給食経 営管理実習を実施している。本対象者は, 大学入学まで の食生活環境において, 調理体験にそしかった者が約 9 割いたことから，入学直後から調理や料理に興味をもた せる動機づけとして，さまざまな課題に取り組ませた。 学生は 1 年次の調理学の初回授業日から 1 週間, 自分の 食生活を評価するため, 食事内容・食事時刻等をありの

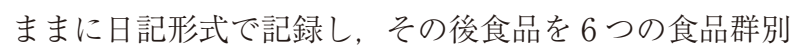
に分類し自己評価させた。この作業を通して，自身の食 事の現状把握と問題点に気づかせた。継続的にその後も 
表 2 臨地実習までの 2 年間の教育内容（科目間の連携授業）

\begin{tabular}{|c|c|c|c|c|}
\hline 学年 & 学期 & 授業科目または授業準備 & 回 & 課題内容 \\
\hline \multirow[t]{11}{*}{1 年 } & 前期 & 調理学 & 1 & 1 週間の食事記録と評価（現状把握） \\
\hline & \multirow[t]{2}{*}{ 夏季休㗇中 } & 調理学実習準備 & 2 & 教科書・料理本等からの調べ学習 \\
\hline & & 調理学実習準備 & 3 & 自作料理の記録（後期終了まで継続） \\
\hline & \multirow[t]{7}{*}{ 後期 } & 調理学実習 & 4 & 1 週間の食事記録と評価（半年後の現状把握） \\
\hline & & 調理学実習 & 5 & 市販品からのオリジナル成分表作り \\
\hline & & 調理学実習 & 6 & 調理実習ごとの作業工程表作成の練習 \\
\hline & & 調理学実習 & 7 & 調理実習ごとの栄養価計算と写真記録 \\
\hline & & 調理学実習 & 8 & 調理実習ごとの課題の調べ学習 \\
\hline & & 調理学実習 & 9 & 実技試験のための課題 \\
\hline & & 給食経営管理論 I & & \\
\hline & 冬季休暇中 & 調理学実習 & 10 & 食文化の調べ学習, 我が家の正月料理の記録 \\
\hline \multirow[t]{2}{*}{2 年 } & 前期 & 給食経営管理論 II & & \\
\hline & 夏季休㗇中 & 給食経営管理実習準備 & $\begin{array}{l}1 \\
2 \\
3 \\
4 \\
5 \\
6 \\
7 \\
8 \\
9\end{array}$ & $\begin{array}{l}\text { (1)和洋中別昼食献立の作成 } \\
\text { (2)主菜は定食用・弁当用の } 2 \text { 種類 } \\
\text { (3)和洋中献立の栄養価計算 } \\
\text { (4)事前に自宅で料理試作 (写真添付) } \\
\text { (5)試作後の自己評価および扡已評価 } \\
\text { (6)和洋中献立の100食あたり原価表の作成（参考：市場価格調査結果) } \\
\text { (7)生産（調理）作業工程表の作成 } \\
\text { (8)料理ごとのサービング数の算出（参考：食事バランスガイド） } \\
\text { (9)卓上栄養メモ作り（和洋中 } 3 \text { 種） }\end{array}$ \\
\hline 学年 & 学期 & 授業科目 & 回 & 実習内容 \\
\hline 2 年 & 後期 & 給食経営管理実習 & $\begin{array}{l}2 \\
3 \\
4 \\
5\end{array}$ & $\begin{array}{l}\text { グループ単位での献立調整および栄養価計算 } \\
\text { 作業工程表作成, 給食実習室内の設備・道具およ゙取り扱い方法の確認 } \\
\text { 献立の試作と評価, 実施献立の決定, 発注表の作成, 役割分担表の作成 } \\
\text { ポスター, チケット作成, 栄養メモの作成, チケット販売 } \\
\text { 役割分担確認と作業工程の説明, 食器数の確認と食器の洗浄 } \\
\text { 前日及び当日の検収作業, 和食献立給食づくり, 生産管理, 衛生管理, 事務 } \\
\text { 管理, 反省会 } \\
\text { 前日及び当日の検収作業, 洋食献立給食づくり, 生産管理, 衛生管理, 事務 } \\
\text { 管理, 反省会 } \\
\text { 前日及び当日の検収作業, 中華食献立給食づくり, 生産管理, 衛生管理, 事 } \\
\text { 務管理, 反省会 } \\
\text { 給食実習室の清掃, 食器数の確認, 在庫管理, 帳簿の整理 }\end{array}$ \\
\hline 3 年 & 前期 & 給食の運営の臨地実習 & & 実習時間 45時間 1 単位 \\
\hline
\end{tabular}

自信につなげるために，夏季休暇中には後期の授業準備 として, 調べ学習と自作料理の記録の課題に取り組ませ た。また後期には調理学実習の初回に再度 1 週間の食事 記録と評価をすることで，自己を再認識する機会を持た せた。さらに調理学実習期間中の課題として，自作料理 の記録 (継続課題)，各自が実際に摂取した市販品の栄 養成分表示を記録させ，各人のオリジナル成分表を作ら せた。また毎回の実習の料理ごとの作業工程表づくりと 栄養価計算，写真記録，調べ学習の課題などに取り組み， 並行して給食経営管理論 I の講義を受講した。 2 年前期 には給食経営管理論 II の講義を受け，夏季休㗇中には， 後期の給食経営管理実習の準備のために，表 2 中にある 9 種類の課題に全員が取り組んだ。 2 年後期にはこれら の課題をもとに，表中に示す給食経営管理実習の実習計 画に従い，学内において実践実習を行った。

学内実習は，担当教員指導の下で，学生自らが給食の 理論と基礎知識を応用して, 実践に移して実習すること
により, 管理栄養士として求められる企画力, 運営能力 · 管理能力を養う場所である。対象者は学内実習が臨地実 習前の基礎的な実践実習であり，各自が準備段階から課 題に取り組んだことで，学生は自主性を育み，グループ で協力しながら，大量調理の給食作りを実践し，それぞ れの役割を全うすることで，意欲的・積極的な態度を学 んだ。

\section{（3）実習施設の種類と給食数}

小学校実習は，実習の実践内容はほほ類似した $\mathrm{N}$ 市 立小学校 16 校（S 群）で実施し，給食数は300～1, 300食 であった。事業所実習は，A群の大手企業 4 箇所の給食 施設で実施し，給食数は $1,000 〜 2,300$ 食であり，一方 B 群は一つの大手企業の関連 6 箇所の給食施設で実施し, 給食数は650〜 5, 500食の給食を提供していた。

規模は, 給食数 1,000 食未満の施設は全体の $56.6 \%$, 1,000 食以上の施設は $43.4 \%$ であった。実習環境のうち

$196(60)$ 


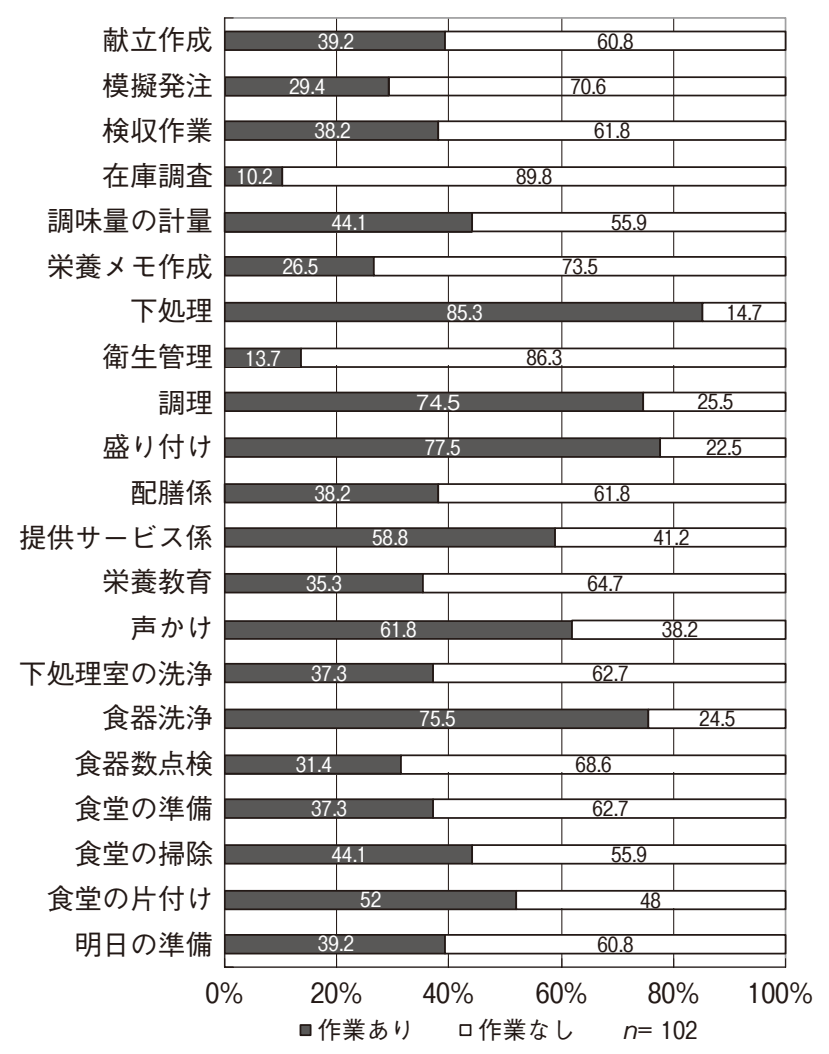

図 1 給食管理（給食の運営）臨地実習中における 作業実施の有無

厨房床がドライシステムでの体験者は， S 群で15.0\%, $\mathrm{A}$ 群で $65.6 \%$, B 群で $6.7 \%$ であり, それ以外の者は ウェットシステムの体験者であった。 $\mathrm{A}$ 群は B 群と比 べて，厨房床のドライ化が進んでいた。

\section{（4）臨地実習中における作業項目の比較}

臨地実習中の作業実施の有無の結果を図 1 に示した。 学内での給食経営管理実習は PDCA サイクルを活用し て実施している。対象者は臨地実習中のさまざまな場面 で体験を積むが，その作業内容は施設ごとで異なる。主 な作業項目としては事前アセスメント，栄養・食事計画， 食材管理, 生産 (調理) 管理, 衛生 - 安全管理, 提供サー ビス, 厨房内作業・その他の項目が挙げられる。具体的 な作業の流れを順にみると，全体の 5 割以上の者が体験 した項目は, 下処理 $85.3 \%$, 調理 $74.5 \%$, 盛り付け77.5\%, 提供サービス $58.8 \%$, 声かけ $61.8 \%$, 食器洗浄 $75.5 \%$, 食堂の片付け52.0\%であり，生産管理面に重点を置いた 作業を実施していた。さらに作業内容が複数ある項目の 下処理作業, 調理作業, 盛り付け作業を作業内容ごとに 分類し集計した結果を図 2-1〜2-3に示した。図 21 の下調理作業項目別では, 主に副菜材料の野菜を切る 作業は全体の $82.4 \%$ ，野菜を洗う作業は56.9\%の者が実 施したのに比べ, 主菜材料の肉, 卵, 魚の作業実施率は 低率であった。図 2-2 の調理作業項目別では, 炒める 作業は53.9\%，煮る作業は $49.0 \%$ ，揚げる作業は $41.2 \%$, 和える作業は $37.3 \%$, 茹でる作業は18.6\%の者が実施し

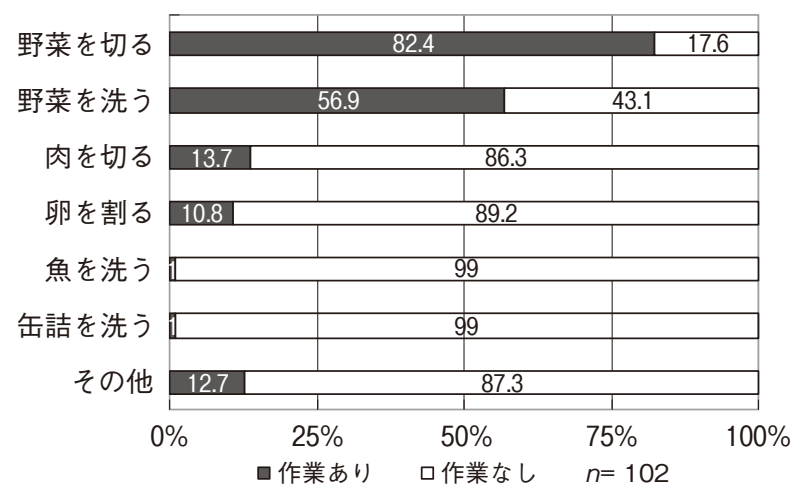

図 2-1 下調理作業項目別の作業実施割合

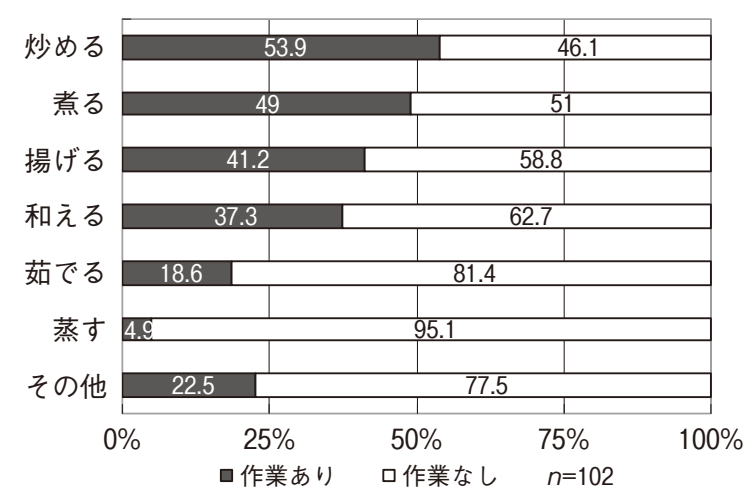

図 2-2 調理作業項目別の作業実施割合

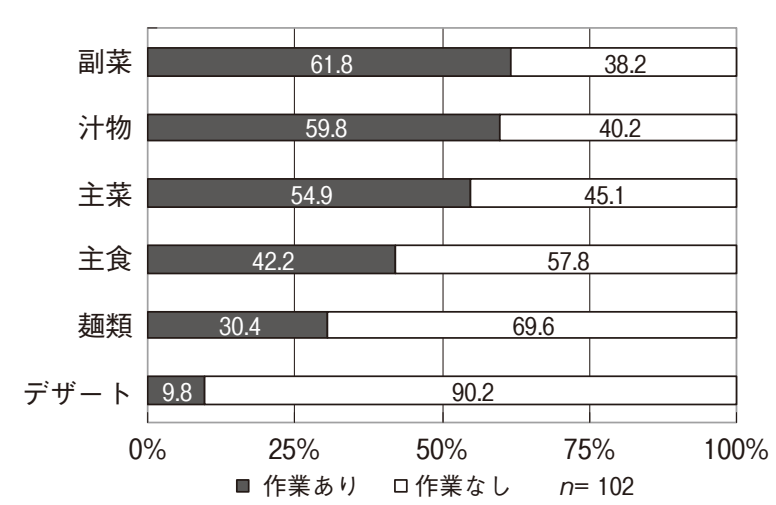

図 2-3 盛り付け作業項目の作業実施割合

ていたが, 蒸す作業はわずかであった。その他の作業に 回答した者は $22.5 \%$ で，スチームコンベクションオーブ ンを使った焼き作業, 材料を混ぜる作業, 食缶に移す作 業などを挙げていた。図 $2-3$ の盛り付け作業項目別では, 副菜担当は $61.8 \%$, 汁物担当は $59.8 \%$, 主菜担当は $54.9 \%$ の者であり, 半数以上の者が盛り付け作業を担当したの に比べて, 主食担当は $42.2 \%$, 曙類担当 $30.4 \%$ でやや低 率であった。

\section{（５）給食施設区分別の作業内容の比較}

作業内容を小学校実習 (S 群) と事業所実習 (A 群, B 群）に分けて，施設別に実習作業項目を比較した結果 を図 3 に示した。施設別に作業実施率の高い順に比較す 


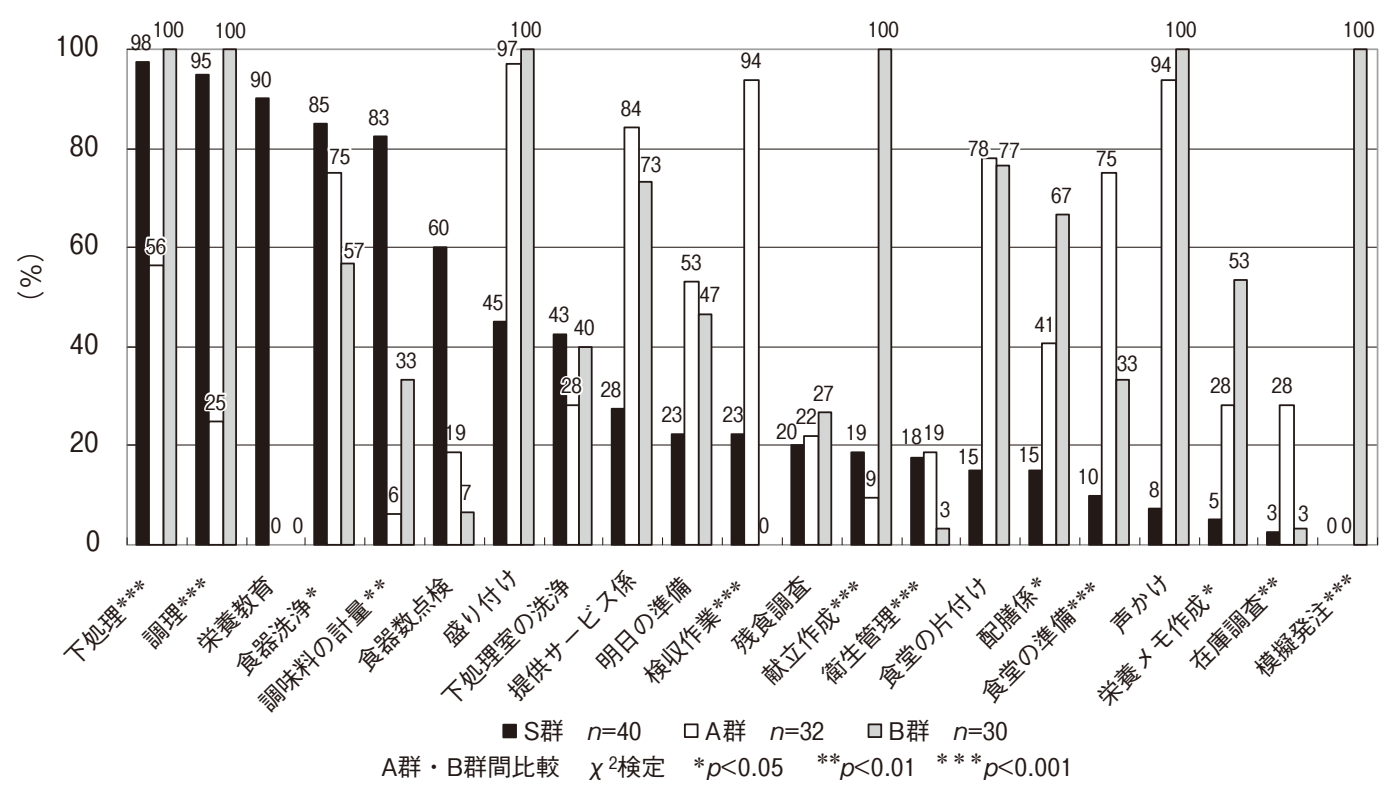

図 3 施設別の実習作業項目の比較

ると，小学校実習の S 群では下処理 $97.5 \%$, 調理 $95.0 \%$, 栄養教育 $90.0 \%$, 食器洗浄 $85.0 \%$, 調味料の計量 $82.5 \%$ であり，いずれも 8 割以上の者がこれらの作業を体験し ていた。事業所実習のA群は, 盛り付け96.9\%, 検収・ 声かけ93. 8\%, 提供サービス係 $84.4 \%$, 食堂の片付け $78.1 \%$, 食器の準備・食品の洗浄 $75.0 \%$, 下処理 $56.3 \%$, 調理 $25.0 \%$ であり，一方，事業所実習の B 群では，下 処理, 調理, 盛り付け, 献立作成, 声かけ, 模擬発注の 6 項目の作業を全員が体験していた。盛り付け作業と声 かけは $\mathrm{A} \cdot \mathrm{B}$ 両群で大多数の者が体験していた。 A·B 群 間で有意差が認められた項目は21項目中12項目であった。 $\mathrm{B}$ 群の実習内容の具体的例は表 3 に示す通りであり，実 習の作業内容の標準化体制が整っていた。 $\mathrm{S}$ 群は小学校 で教育機関であることから給食を「生きた教材」として 食育の一環と捉え，対象者の $90.0 \%$ 者が給食時間に児 童への栄養教育を実施していた。一方で事業所では栄養 メモの作成を A 群は28.1\%, B 群は53.3\%で実施し, 2 群間で 2 倍の格差がみられた。また模擬発注作業は $\mathrm{S}$ 群および $\mathrm{A}$ 群では全く行われていなかった。以上の結 果から, A 群 · B 群別作業内容の特徴として, A 群は事 前のオリエンテーションは実施していたが，実習内容は 施設間で統一はなく，実習内容の標準化もされておらず， 6 施設別に実習内容を決めている実態がわかった。一方, $\mathrm{B}$ 群は事前のオリエンテーションの際, 実習スケジュー ル, 課題, 実習計画, 嘚房作業計画・作業スケジュール 厨房実習要領を書面にて詳細に提示し，4施設で同一の 標準化された実習内容が実施され，実習生全員に実習内 容の統一化が図られ，受け入れ体制も整備されているこ とがわかった。

\section{（6）学内および学外実習における自己評価の比較} 学内および学外実習における自己評価を比較した結果
を表 4 に示した。学内での給食管理実習後に実施した自 己評価の集計結果によると，評価の高い順は「身支度は 清潔にできたか」・「実習時間を守ったか」の項目は3.1点, 「協力的にできたか」では2.9,「衛生・安全に心がけたか」 では2.8点,「自主的・積極的に行動できたか」・「責任を 持って行動できたか」・意思表示がはっきりできたか」・ 「給食の運営が理解できたか」では2.6点であり，時々で きなかったとする評価の 2 点よりはいずれも高い評価と なった。一方, 学外の給食運営臨地実習直後の自己評価 結果では，いずれの項目も学内実習と比べて，すべて高 い点数を付けた。評価点の伸びの高い順は実習前と比べ て「意思表示がはっきりできたか」1.35倍，「体調はべ ストであったか」1.33倍, 「事前の準備（予習など）を 十分行って臨んたか」1.32倍, 「責任をもって行動でき たか」1.31倍,「衛生・安全に心がけたか」1.28倍,「給 食の運営を理解することができたか」1.27倍，「実習時 間を守ったか」1.26倍などであった。それぞれの点数を 臨地実習前後で比較すると, いずれの項目も, 臨地実習 後の評価は実習前と比べて, 評価点は有意に高值 $(p<0.001)$ となり，学外での実践実習の効果が大きいこ とが示された。

\section{（7）小学校実習と事業所実習の比較}

給食運営臨地実習後の対象者の満足度 - 達成感は, 実 習先の体験内容によって異なると予想した。「学内実習 の体験が臨地実習で役立ったか」，「特定給食施設の栄養 士の仕事内容が把握できたか」,「給食施設別に給食の運 営を理解することができたか」について，5段階評価し た結果を小学校実習 (S 群) と事業所実習 (A 群, B 群) で比較し図 4-1〜 4-3に示した。

「学内実習の体験が臨地実習で役立ったか」を比較し た結果を図 4-1に示した。「十分役立った・まあまあ役 
表 3 標準化体制の B 社施設における共通の実習スケジュール例

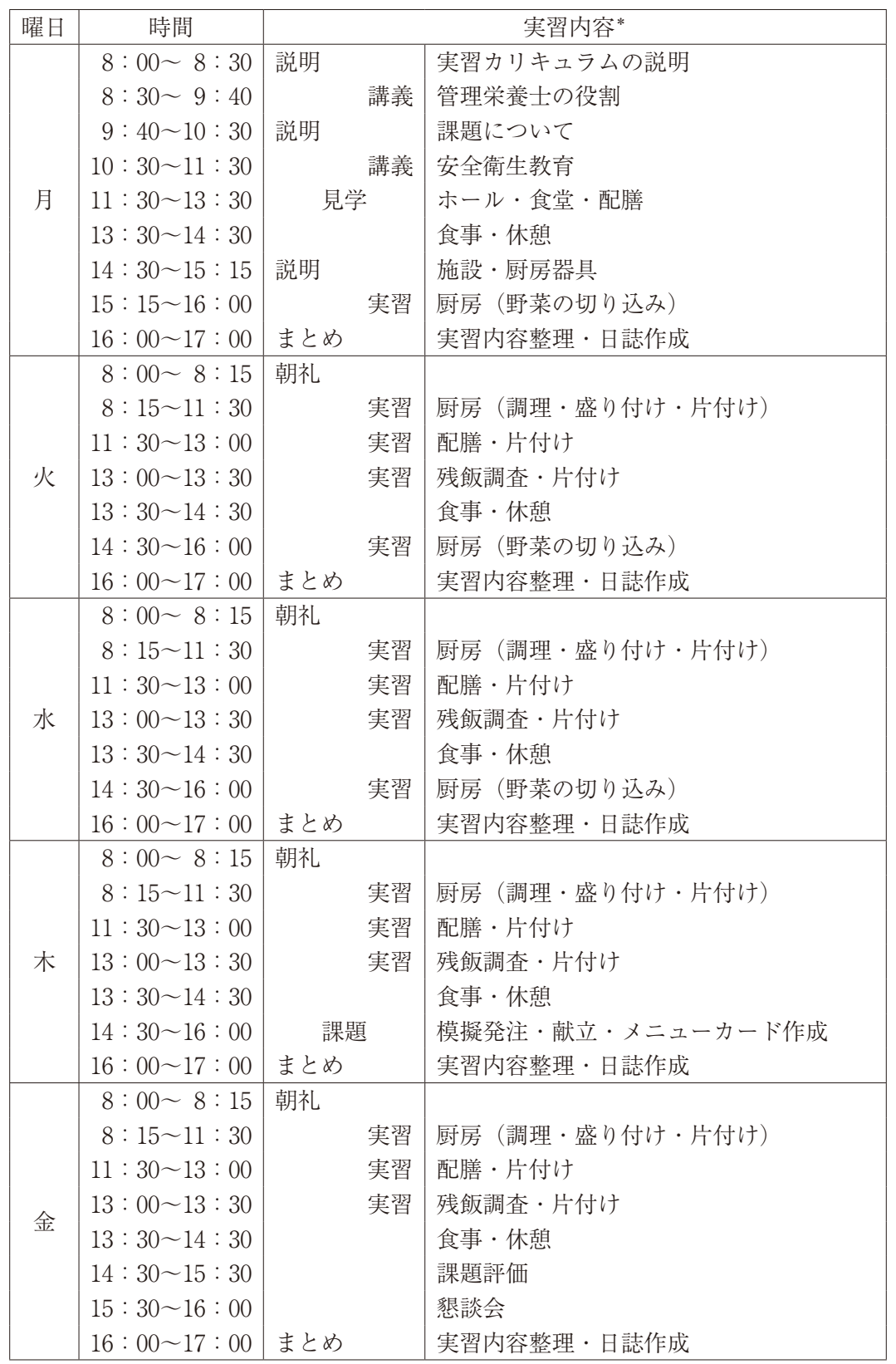

*ただし，事情により，時間帯，実習内容は多少異なる場合がある。

立った」と回答した者の割合は $\mathrm{B}$ 群， $\mathrm{A}$ 群， $\mathrm{S}$ 群の順で 高く, $\mathrm{S}$ 群は小学校実習の特殊性が， A·B 群は学内実習 内容との関連性が窅われた。自己評価の平均評価点を比 ベると B 群4. 0点, A 群3.8点, $\mathrm{S}$ 群3.6点の順であり, $\mathrm{S}$ 群， $\mathrm{A}$ 群， $\mathrm{B}$ 群の 3 群間で比較すると有意差はみられな かった。

「特定給食施設での栄養士の仕事は把握できたか」を 比較した結果を図 4-2 に示した。「十分把握できた・ま あまあ把握できた」と回答した者の割合は B 群，S 群， $\mathrm{A}$ 群の順で高く, $\mathrm{A}$ 群で「全く把握できなかった」と回 答する者が $12.5 \%$ で他の群と比べて多かったが平均評価 点の高い順は $\mathrm{B}$ 群4.2点, $\mathrm{S}$ 群4.1点, $\mathrm{A}$ 群3.7点であり, $\mathrm{A}$ 群の評価はやや低かったが, 3 群間で有意差はみられ なかった。
「給食施設別に給食の運営を理解することができたか」 を比較した結果を図 4-3に示した。「大変よくできた。 よくできた」と回答した者は, S 群で $95.0 \%, \mathrm{~A}$ 群 $90.6 \%$, $\mathrm{B}$ 群 $94.6 \%$ で, $\mathrm{A}$ 群は $\mathrm{S}$ 群, B 群と比べて, やや低率で あったが、いずれも 9 割以上の者がこの臨地実習から， 給食の運営を理解できたと回答した。

\section{4. 考察}

管理栄養士養成を念頭に㧍きながら，学生自身が「気 づき」「「知る」・「考える」・「学ぶ」ことで管理栄養士に 必要な思考力, 判断力, 表現力その他の能力を育み, 自 らが自主的に主体的に行動できる力を育むことは重要で ある。対象者は臨地実習に入るまでの 2 年間の準備段階 において，授業時間外にさまざまな課題に取り組んでき 
表 4 実習の自己評価

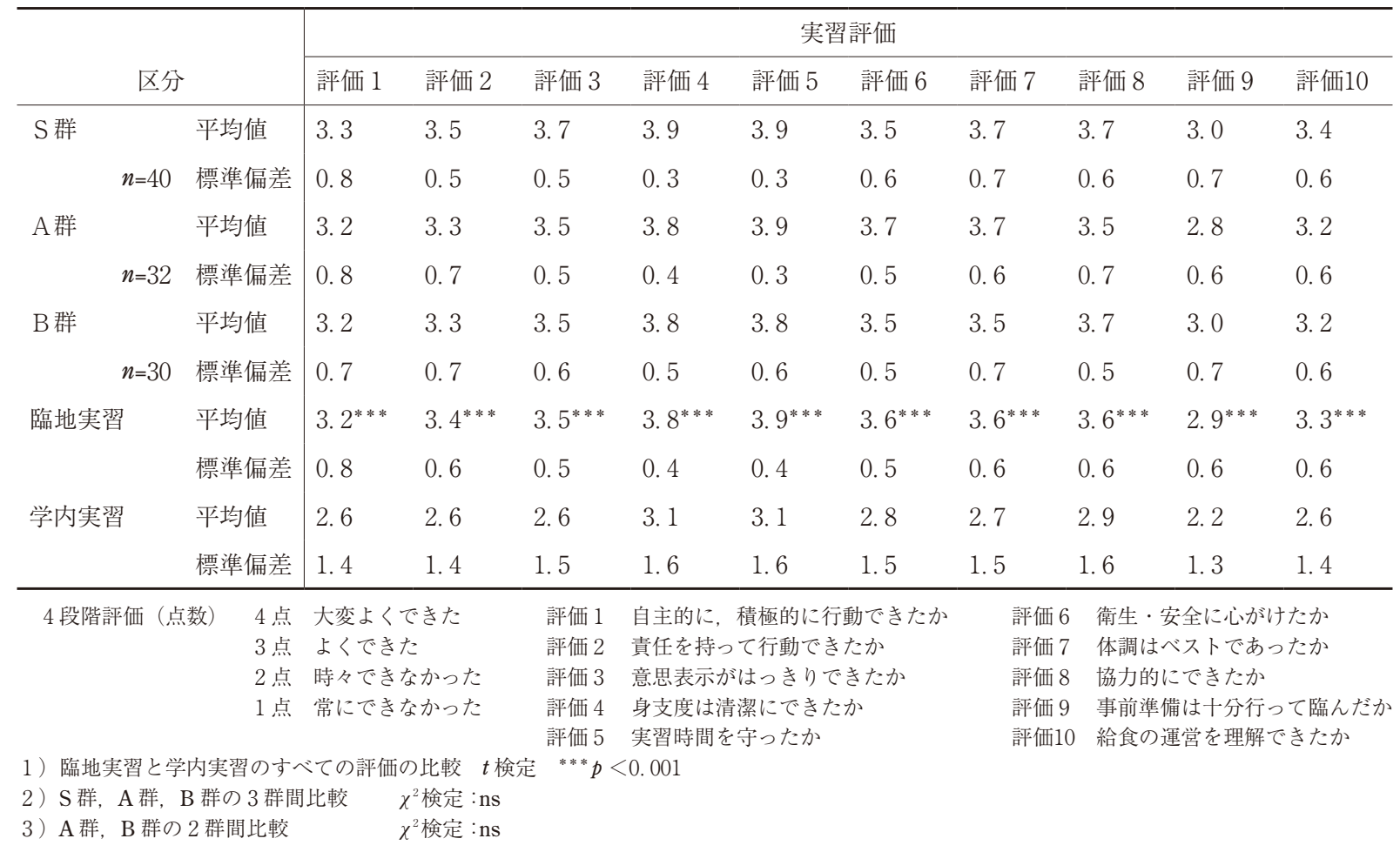

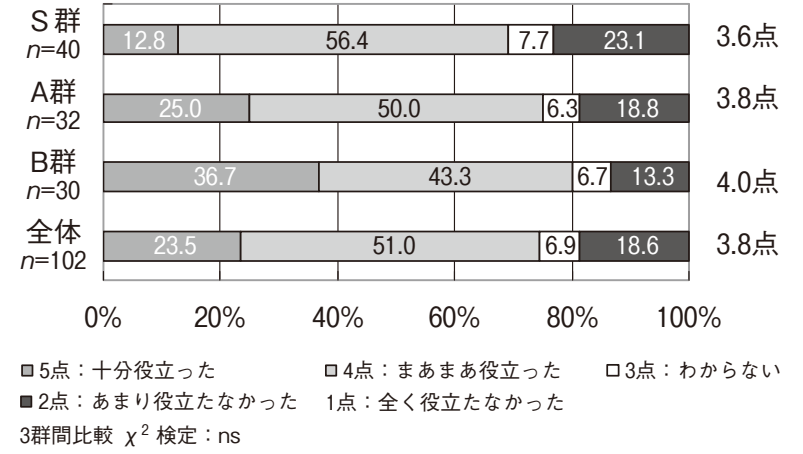

図 4-1 学内実習の体験が臨地実習で役立ったか

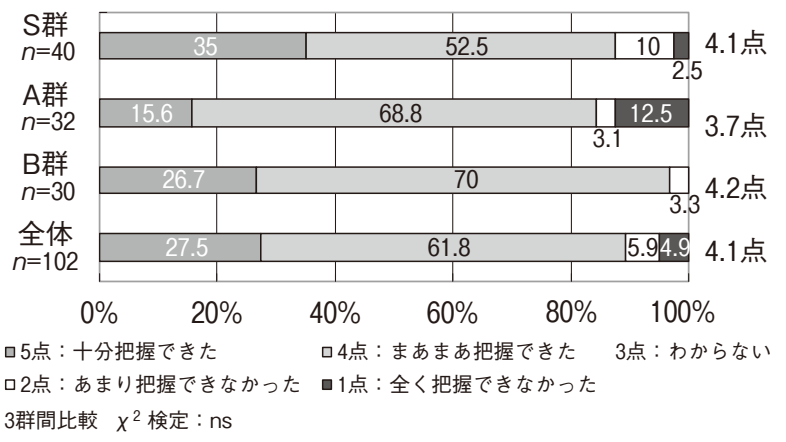

図 4-2 特定給食施設での栄養士の仕事は把握できたか

た。

近年の入学生は, 家庭においてほとんど調理体験を持 たないまま入学する者が多いために, 調理実習面に対し て精神的不安をかかえている者が多い実態があった。そ こで「気づき」行動として， 1 年前期には，入学直後の 1 週間の食事日記の自己評価を行い, 後期には, 再度前

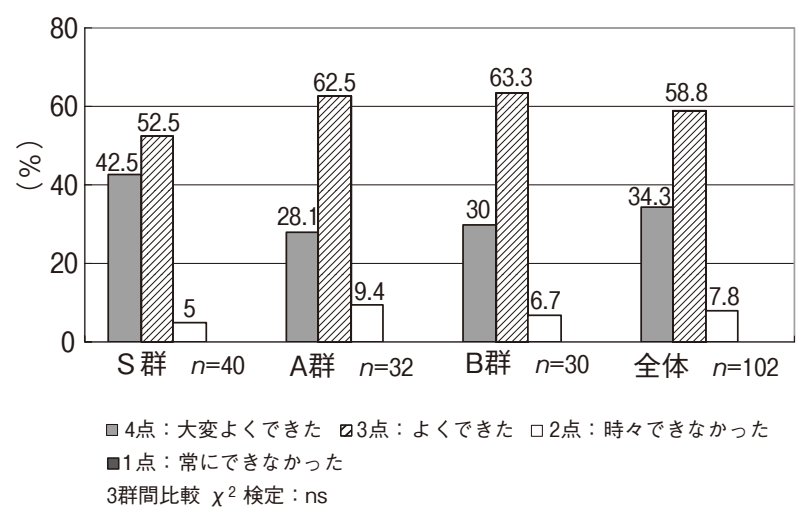

図 4-3＼cjkstart給食の運営を理解することができたか

期同様の 1 週間の課題およびオリジナル成分表づくりに 取り組み，自己の実態に気づかせた。さらに「知る」・「 考える」行動として, 調べ学習, 作業工程表づくりなど に取り組ませた。 2 年の夏季休暇中には, 後期の学内実 習の課題に取り組むなど, 3 年の臨地実習に向けての学 習の積み上げを行ってきた。対象者らは，学内において 座学から実学への基礎的な学びの過程を経た後, 自己体 験を基礎として，実践現場となる臨地実習でのさまざま な作業体験を積んだ。これらの過程を経て，学生自身が 実習現場で何に「気づき」・「知り」・「考え」・「学んだ」 かにより，その後の更なる成長が期待される。

しかし，本調査結果によると，給食運営臨地実習では, 実習施設の状況により, 「学ぶ」内容が異なり, 差がみ られた。特に事業所実習において A 群，B 群を比較す ると, 実習内容に明らかな格差が認められ, 実習施設側 の実習体制の充実度や管理栄養士のかかわり方によって 
も，対象者の自己評価に差があることが明確となった。 対象者自身の能力にもよるが, 臨地実習で達成感を得た 者, 積極的に取り組めた者, 積極性が薄れた者などさま ざまであり，受け入れ体制が対象者の意識に反映された と考えられる。また, 本調査において臨地実習の作業内 容が学内実習での作業実態に近い施設ほど，自己評価は 高くなり，また作業内容や管理栄養士とのかかわりがそ しいと感じた施設での実習の評価は低くなった。しかし， 臨地実習後の自己評価をみると, いずれの対象者も学内 実習の自己評価より, 評価点が高まった。つまり対象者 は臨地実習前の学内体験が基となり, 臨地実習の実践現 場でのさまざまな体験を積んだことで, より一層, 共同 作業の大切さやコミュニケーション力, 思考力, 判断力, 表現力の必要性を実感し, 総合的に判断して, 臨地実習 後の自己評価点の向上につながったと考えられる。

養成施設での給食経営管理論の講義は, 管理栄養士ガ イドラインに準じた内容を教授するが，その学内実習は， 臨地実習での作業内容を想定し, 基本的な作業内容を網 羅し実施している。しかし, 臨地実習先の作業内容が基 本と乘離することは避けなければならないと考える。臨 地実習先の管理栄養士は, 日常の煩雑な業務に加えて実 習生を受け入れている現状にある。実習生は不安と期待 感を持って実習に臨むが, 一方でやる気, 学ぶ姿勢, 謙 虚な気持ちを態度で表すべきであろう。臨地実習は実習 生にとって現場の管理栄養士の実像に接する絶好の機会 であり，学びの場でもある。養成校の教員も現場の管理 栄養士も, 己の一挙一動が実習生の手本となり, 給食業 務の基本と連動し，応用力を教授する担い手として，ま た実習生の教育者としての自覚を持ち続けなければなら ないと考える。今後の課題としては, 大学間, 実習先と の連携を密にして，お互いが管理栄養士の養成に携わる 者としての自覚を持ち, 手を携えて, 将来を担う管理栄 養士養成のために, 満足感を与えられるような指導内容 の充実に務める必要性を実感した。

\section{5. 要 約}

給食経営管理論領域に関連する臨地実習に着目し, 今 後の授業運営と臨地実習のあり方を検討する基礎資料を 得る目的で，実習内容に関する実態調査を実施した。

(1) 給食数は 1,000 食未満の施設が $56.6 \% ， 1,000$ 食以 上の施設が $43.4 \%$ であった。

（2）臨地実習中に体験できた項目は，学生全体の50\% 以上の者が下処理, 調理, 盛り付け, 提供サービス, 声かけ, 食器洗浄, 食堂の片付けであり, 生産管理面
に重点を置いた実習が実施されていた。実習項目ごと で作業の多い順にみると, 下処理作業では野菜切り, 野菜洗浄, 調理作業では炒める, 煮る, 揚げる, 和え る, 盛り付け作業では副菜, 汁物, 主菜であった。

（３）施設別では，小学校施設では下処理，調理，栄養 教育, 食器洗浄, 調味料の計量の順で多く, 事業所施 設の A 群は盛り付け，検収・声かけ，提供サービス， 食堂の後片付けなどを約 8 割以上の者が実習し，B群 は下処理, 調理, 盛り付け, 献立作成, 声かけ, 模擬 発注の 6 項目を全員が体験し作業内容の標準化体制が 整っていた。

（4）学内および学外の実習の自己評価を比較すると, 学内実習と比べて, 臨地実習はいずれの項目も評価点 が有意に高く，学外での実践実習の効果が示された。

（５）臨地実習で栄養士業務が「十分把握できた者・ま あまあできた者」は，全体の91.2\%であり，B群， S 群， $\mathrm{A}$ 群の順で把握の割合が高かった。給食の運営を「大 変よく理解できた者・よくできた者」は全体の $92.2 \%$ であり, 施設別の評価点の平均值は小学校が高く, A 社の事業所で低かった。施設別に実習内容の差が確認 でき，今後の実習指導上の課題が明らかとなった。

\section{謝辞}

本調査をまとめるにあたり，資料をご提供いただきま したメイフード株式会社取締役社長堂本栄一様, 管理栄 養士加藤幹子様に感謝申し上げます。

\section{文献}

1）日本栄養士会・全国栄養士施設協会編：臨地・校外実習 の実際一改正栄養士法の施行にあたって一2002年版, p. 1 5 (2002)

2 ) 西村早苗, 石田裕美, 武見ゆかり, 渡邊早苗, 岡崎光子, 太田和枝, 吉田企世子, 二見大介：管理栄養士養成に扔け る臨地実習プログラムの開発に関する研究一臨地実習に対 する学生のニーズと実習後の自己評価一, 女子栄養大学紀要, 34, 115-121 (2003)

3 ）西村早苗, 石田裕美, 亀井明子, 武見ゆかり, 吉岡有紀子, 三浦理代，二見大介：管理栄養士養成に打ける臨地実習プ ログラムの開発に関する研究 第 2 報一公衆栄養学領域, 給食管理 (学校) 領域の実習時間別の検討一, 女子栄養大 学紀要, 35, 103-110 (2004)

4) 北島葉子, 川上祐子, 横山純子, 村上淳, 高早苗, 佐々 木敦子, 上田由喜子, 菅淑江：臨地実習に扔ける実習効果 を高めるための検討, 中国学園紀要, 4, 1-8（2005）

5 ) 殿塚婦美子, 三好恵子編著：改訂 給食運営管理実習 · 学内編 学内実習ノート, 建帛社, 東京, p.40（2012） 